\title{
Differential Responses of Soil Organic Carbon Fractions and Carbon Turnover Related Enzyme Activities to Wheat Straw Incorporation in Subtropical China
}

\author{
Wei Dai ${ }^{1}$, Kaikai Fang ${ }^{1}$, Hui Gao ${ }^{1}$, Jun Wang ${ }^{1}$, Petri Penttinen ${ }^{2}$, Zhimin Sha ${ }^{1, *}$ and Linkui Cao ${ }^{1, *}$ \\ ${ }^{1}$ School of Agriculture and Biology, Shanghai Jiaotong University, Shanghai, 200240, China \\ ${ }^{2}$ Department of Microbiology, College of Resources, Sichuan Agricultural University, Chengdu, 611130, China \\ *Corresponding Authors: Zhimin Sha. Email: zhiminsha@sjtu.edu.cn; Linkui Cao. Email: clk@sjtu.edu.cn \\ Received: 03 March 2021 Accepted: 23 April 2021
}

\begin{abstract}
Soil organic carbon (SOC) fractions and C turnover related enzyme activities are essential for nutrient cycling. This is because they are regarded as important indicators of soil fertility and quality. We measured the effects of wheat straw incorporation on SOC fractions and $\mathrm{C}$ turnover related enzyme activities in a paddy field in subtropical China. Soil samples were collected from $0-10 \mathrm{~cm}$ and $10-20 \mathrm{~cm}$ depths after rice harvesting. The total SOC concentrations were higher in the high rate of wheat straw incorporation treatment (NPKS2) than in the not fertilized control $(\mathrm{CK})(P<0.05)$. The concentrations of labile $\mathrm{C}$ fractions [i.e., water soluble organic $\mathrm{C}$ (WSOC), hot-water soluble organic C (HWSOC), microbial biomass C (MBC), and easily oxidizable C (EOC)], were higher in the moderate NPKS1 and NPKS2 treatments than in CK and the fertilized treatment without straw (NPK) $(P<0.05)$. The geometric means of labile $\mathrm{C}(\mathrm{GMC})$ and $\mathrm{C}$ pool management index $(\mathrm{CPMI})$ values were highest in NPKS2 $(P<0.05)$. The SOC concentrations correlated positively with the labile $\mathrm{C}$ fractions $(P<0.05)$. Soil cellulase activity and the geometric mean of enzyme activities (GMea) were higher in NPKS2 than in CK in all soil layers $(P<0.05)$, and the invertase activity was higher in NPKS2 than in CK in the $0-10 \mathrm{~cm}$ layer $(P<0.05)$. Stepwise multiple linear regression indicated that the formation of the SOC, WSOC, HWSOC, MBC, and EOC was mostly enhanced by the cellulase and invertase activities $(P<0.05)$. Therefore, the high rate of wheat straw incorporation may be recommended to increase soil $\mathrm{C}$ pool levels and soil fertility in subtropical paddy soils.
\end{abstract}

\section{KEYWORDS}

Wheat straw incorporation; soil organic carbon fractions; soil carbon turnover related enzymes; paddy soil; subtropical China

\section{Introduction}

Organic carbon (C) content in soil affects soil physical biochemical properties, and is therefore a vital factor responsible for soil fertility and productivity [1]. The maintenance of SOC content is crucial for the sustainability of agricultural ecosystems. SOC dynamic is affected by many agricultural management practices (e.g., fertilizer application, straw incorporation, and tillage) [2-4]. However, SOC content changes are hard to monitor in the short time likely because of the considerable background $\mathrm{C}$ content [5-7]. The labile fractions of SOC, e.g., water soluble organic C (WSOC), hot-water soluble organic C (HWSOC), microbial biomass $\mathrm{C}(\mathrm{MBC})$, and easily oxidizable $\mathrm{C}$ (EOC), are seen as early and sensitive 
indicators of soil quality changes that result from soil management practices [5,8-10]. The $\mathrm{C}$ pool management index (CPMI), which was developed to evaluate the status and rate of SOC changes in agroecosystems based on the total SOC and EOC, is a useful parameter in assessing the influences of management practices on soil quality [5].

The decomposition and accumulation of SOC in agroecosystems can be affected by crop straw, agricultural waste rich in organic $\mathrm{C}$ [10]. The direct and indirect straw incorporation into soil can balance the SOC loss resulting from SOC mineralization in agroecosystems [10-11]. Compared with the NPK fertilizers application alone, the SOC change rate was approximately two times higher in straw application treatments in paddy fields [12]. In addition, the WSOC and MBC contents were higher in the top $20 \mathrm{~cm}$ soil after a short-term (less than two-years) straw application [13]. Wang et al. [14] revealed that incorporation of straw into soil enhanced the total SOC content in dryland farming, especially with the higher straw incorporation rate. Moreover, the turnover of SOC is mainly associated with soil microbial community functions (e.g., enzyme activities) [15-16]. Several soil enzymes participate in the decomposition of SOC, thus further influencing SOC fractions, and the enzyme activities are also important indicators of soil fertility and quality [16-18]. For example, cellulase, invertase, and $\beta$ glucosidase that decompose SOC indicate the metabolic abilities of the soil microbial community and the utilizable C resources $[2,19]$. Previous studies on soil enzymes related to the SOC turnover mostly paid attention to the grassland and forest ecosystems [15-16,20,21]. Knowledge on crop straw incorporation in agroecosystems is still lacking, especially in the subtropical paddy soils. Organic C may accumulate in the subtropical paddy soils faster than in other soils [22], possibly due to regular and periodic changes between aerobic and anaerobic conditions due to the management [23]. In particular, Tang et al. [24] demonstrated that subtropical paddy soils are markedly responsive to global climate change and management practices (e.g., to crop straw incorporation). This necessitates studying the effects of crop straw incorporation practices on changes in SOC fractions and the corresponding $\mathrm{C}$ turnover related enzyme activities in the subtropical paddy soils. Understanding the relationships between SOC fractions and enzymes can reveal the potential mechanisms in SOC turnover and $\mathrm{C}$ cycle under straw incorporation practices $[13,25,26]$.

In China, almost $0.80 \mathrm{Pg}$ of straw residue is produced annually, and the rate is currently increasing [27]. More than three tenth of the straw produced is burned directly in open fields [28], which has led to severe environmental pollution (e.g., fine particulate matter) in the past decades [29]. Straw incorporation is regarded as an environment-friendly management practice that can reduce air pollution and supply organic $\mathrm{C}$ to soils [10,27]. A full understanding of the effects of wheat straw incorporation on SOC fractions and $\mathrm{C}$ turnover related enzyme activities in paddy field is essential to assess the sustainability of straw incorporation practices. Hence, the objectives of this study were to (1) examine the dynamic changes in SOC fractions and $\mathrm{C}$ turnover related enzyme activities, and (2) explore the relationships between SOC fractions and the corresponding enzyme activities.

\section{Materials and Methods}

\subsection{Experimental Site}

The experimental field (May 2019-November 2019) was in the Modern Agricultural Park of Qingpu, Shanghai, China $\left(121^{\circ} 01^{\prime} \mathrm{E}, 31^{\circ} 08^{\prime} \mathrm{N}\right.$ ) (Fig. 1). The study area is characterized by a subtropical monsoon climate, with an average annual precipitation and temperature of $1056 \mathrm{~mm}$ and $15.5^{\circ} \mathrm{C}$, respectively. The annual daylight hours are $1960.7 \mathrm{~h}$, and the frost-free days are $247 \mathrm{~d}$. The rice-wheat rotation system is the major cropping system in the region. The soil has a clay loam texture, with initial soil properties $(0-20 \mathrm{~cm})$ as follows: $\mathrm{pH} 7.08$, bulk density $1.16 \mathrm{~g} \mathrm{~cm}^{-3}$, SOC $16.59 \mathrm{~g} \mathrm{~kg}^{-1}$, total N $1.96 \mathrm{~g} \mathrm{~kg}^{-1}$, available $\mathrm{N} 140.47 \mathrm{mg} \mathrm{kg}^{-1}$, available $\mathrm{P} 36.51 \mathrm{mg} \mathrm{kg}^{-1}$, and available $\mathrm{K}_{146 \mathrm{mg} \mathrm{kg}} \mathrm{m}^{-1}$. 


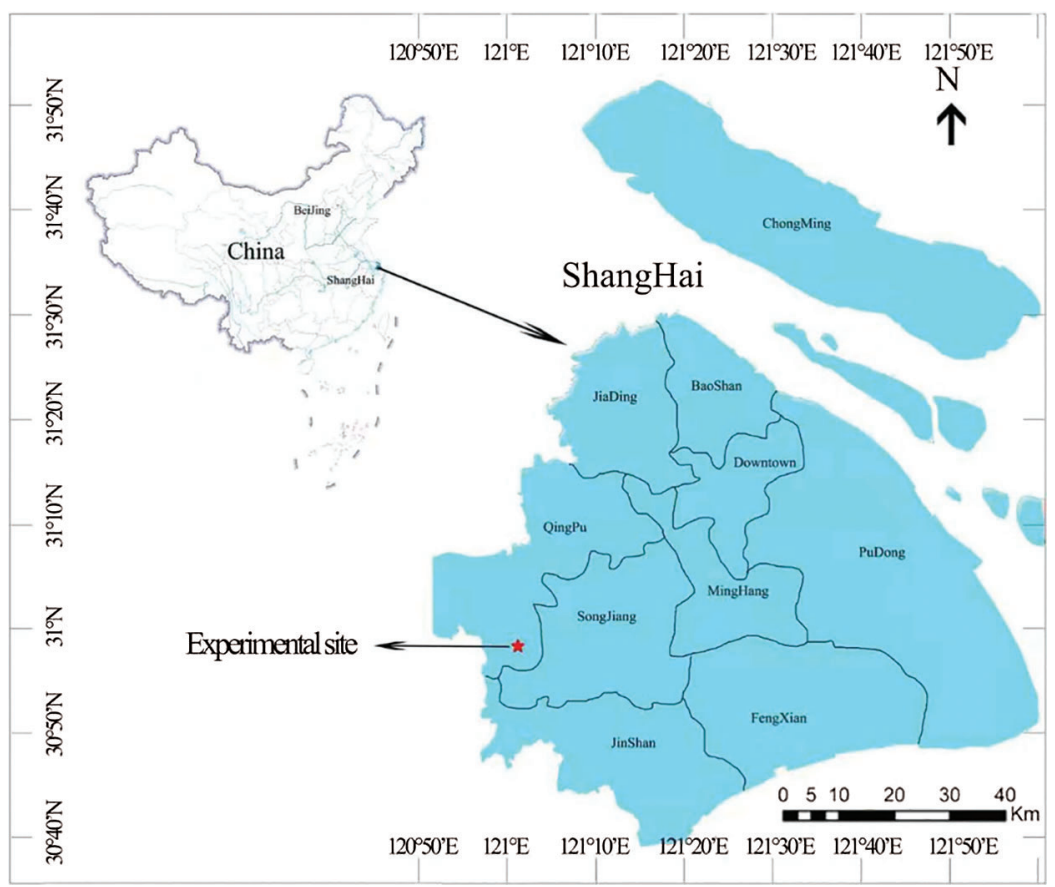

Figure 1: Location of the field experimental site

\subsection{Experimental Design and Soil Sampling}

Fig. 2 presents the experimental design, which included four treatments: (1) no fertilizer and wheat straw (CK), (2) mineral nitrogen, phosphorus, and potassium fertilizers (NPK), (3) moderate wheat straw (3000 kg ha ${ }^{-1}$ ) combined with NPK (NPKS1), and (4) high wheat straw $\left(6000 \mathrm{~kg} \mathrm{ha}^{-1}\right)$ combined with NPK (NPKS2). The moderate and high rates were equivalent to about $50 \%$ and $100 \%$, respectively, of the harvested wheat straw yield. The treatments were laid out in a randomized block design in triplicate with an $8 \times 7 \mathrm{~m}$ plot. The wheat straw was chopped and then incorporated into the paddy soil using conventional tillage. Fertilizers were applied as $300 \mathrm{~kg} \mathrm{ha}^{-1} \mathrm{~N}, 120 \mathrm{~kg} \mathrm{ha}^{-1} \mathrm{P}$, and $150 \mathrm{~kg} \mathrm{ha}^{-1} \mathrm{~K}$, including urea $(46 \% \mathrm{~N})$, calcium superphosphate $\left(12 \% \mathrm{P}_{2} \mathrm{O}_{5}\right)$, and potassium chloride $\left(60 \% \mathrm{~K}_{2} \mathrm{O}\right)$. $\mathrm{N}$ fertilizer was applied as follows: $40 \%$ at the sowing stage, $30 \%$ at the tillering stage, and $30 \%$ at the panicle stage. Both $\mathrm{P}$ and $\mathrm{K}$ fertilizers were applied before transplanting the rice. Other field management practices (e.g., the water regime), were in line with the local farmers' practices.

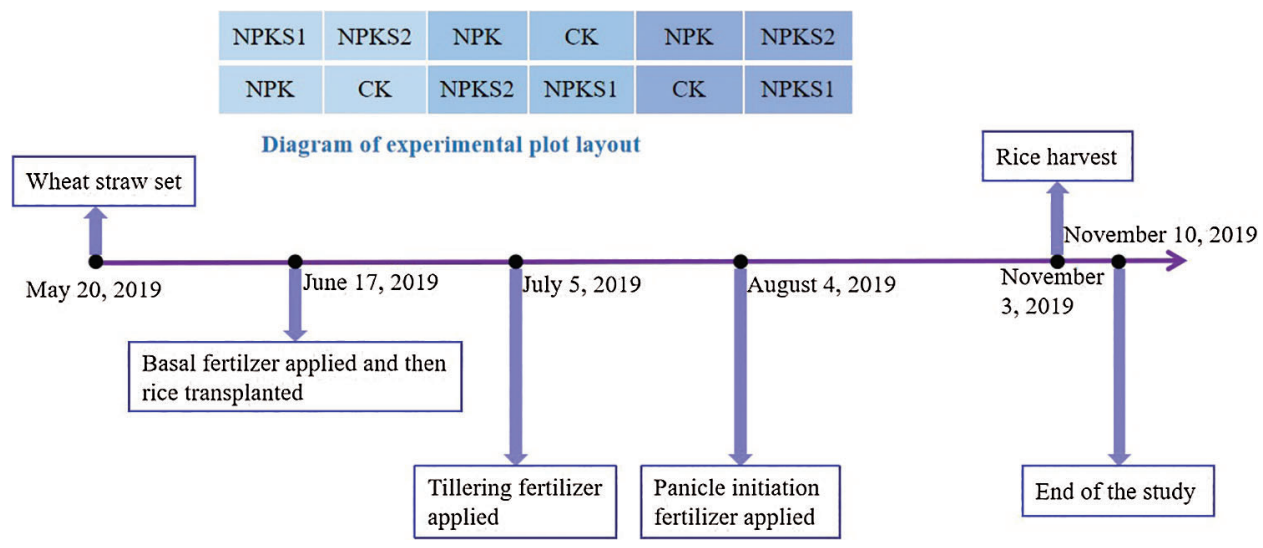

Figure 2: Field experimental design. CK: no fertilizer and wheat straw; NPK: mineral nitrogen, phosphorus, and potassium fertilizers; NPKS1: moderate wheat straw $\left(3000 \mathrm{~kg} \mathrm{ha}^{-1}\right)$ combined with NPK; NPKS2: high wheat straw $\left(6000 \mathrm{~kg} \mathrm{ha}^{-1}\right)$ combined with NPK 
Soil samples were collected from $0-10 \mathrm{~cm}$ and $10-20 \mathrm{~cm}$ depths after rice harvest at five random points in each plot, and then mixed to form a composite sample. Following the removal of visible stones and plant residues, the samples were homogenized, passed through a $2 \mathrm{~mm}$ mesh, and then divided into two subsamples. One subsample was stored at $4^{\circ} \mathrm{C}$ for the analysis of WSOC and MBC within 10 days, and the other subsample was air-dried for the measurements of SOC, HWSOC, EOC, cellulase, invertase, and $\beta$-glucosidase activity.

\subsection{Soil Analysis}

\subsubsection{SOC Fractions Analysis}

SOC was determined using an elemental analyzer (Vario EL III, CHNOS Elemental Analyzer, Elementar, Langenselbold, Germany). The WSOC was determined by extracting the fresh soil samples with water at a soil/water ratio of $1: 5$ and analyzing the $\mathrm{C}$ concentrations using the Multi N/C 3100 Analyzer (Analytik Jena, Germany) [30]. The HWSOC was determined on fresh soil samples using the method of Sparling et al. [8] and C concentrations were measured using the Multi N/C 3100 Analyzer (Analytik Jena, Germany). MBC was determined using the chloroform fumigation-extraction method [31] and was calculated as $\left(\mathrm{C}_{\text {fumigated }}-\mathrm{C}_{\text {non-fumigated }}\right) / 0.45$. EOC was determined using the $333 \mathrm{mmol} \mathrm{L} \mathrm{L}^{-1}$ $\mathrm{KMnO}_{4}$ oxidation method and was calculated as the difference between the amount of $\mathrm{KMnO}_{4}$ added and that remaining [5]. The geometric means of labile $\mathrm{C}$ (GMC) was calculated based on the method of $\mathrm{Yu}$ et al. [32] as follows:

$\mathrm{GMC}=\sqrt[4]{\mathrm{WSOC} \times \mathrm{HWSOC} \times \mathrm{MBC} \times \mathrm{EOC}}$

The CPMI was calculated as follows [5]:

$\mathrm{CPMI}=\mathrm{C}$ Pool Index $(\mathrm{CPI}) \times$ Lability Index $(\mathrm{LI}) \times 100$

The CPI and LI were calculated as follows:

$\mathrm{CPI}=\frac{\text { SOC content in sample soil }}{\text { SOC content in reference soil }}$

$\mathrm{LI}=\frac{\mathrm{L} \text { in sample soil }}{\mathrm{L} \text { in reference soil }}$

The lability of $\mathrm{C}(\mathrm{L})$ is defined as the ratio of labile $\mathrm{C}$ (EOC) to non-labile $\mathrm{C}$, and non-labile $\mathrm{C}$ is calculated as SOC-EOC. In this study, the soil sampled in the control treatment was used as the reference soil.

\subsubsection{Soil Enzyme Activity Analysis}

The cellulase and invertase activities were analyzed based on the methods described by Guan [33], and carboxymethyl-cellulose and sucrose were used as substrates, respectively. Their activities were expressed as the mass $(\mathrm{mg})$ of glucose in $1 \mathrm{~g}$ of soil. The $\beta$-glucosidase activity was determined using a substrate of $p$-nitrophenyl- $\beta$ - $D$-glucopyranoside (PNP) solution and it was expressed as $\mu$ mol $p$-nitrophenol (PNP) in $1 \mathrm{~g}$ of soil [34]. The geometric mean of enzyme activities (GMea) was calculated based on the method of Roberto et al. [35] as follows:

GMea $=\sqrt[3]{\text { Cellulase } \times \text { Invertase } \times \beta-\text { glucosidase }}$

\subsection{Statistical Analysis}

Differences in SOC fractions and C turnover related enzyme activities were tested using the Duncan's Multiple Range Test in SPSS 22.0 (SPSS Inc., Chicago, IL, USA). 
Pearson's correlation analysis was used to determine the relationships between SOC fractions and soil C turnover related enzyme activities. The relationships between SOC fractions and $\mathrm{C}$ turnover related enzyme activities were examined using the general linear-regression analysis and stepwise regression analysis in SPSS 22.0 (SPSS Inc., Chicago, IL, USA). The data were transformed as necessary to satisfy assumptions of normality and homogeneity of variance, and significant levels were set at the 0.05 level.

\section{Results}

\subsection{SOC Fractions}

In the $0-10 \mathrm{~cm}$ and $10-20 \mathrm{~cm}$ soil layers, the SOC concentrations were higher in NPKS2 than in CK $(P<0.05$, Fig. 3a), and the WSOC, HWSOC, MBC, and EOC concentrations were higher in NPKS2 than in NPK and CK $(P<0.05$, Figs. 3b-3e). On average, the WSOC constituted from $0.53 \%$ to $0.83 \%$, HWSOC from $2.86 \%$ to $4.09 \%$, MBC from $2.22 \%$ to $2.70 \%$, and EOC from $17.67 \%$ to $32.65 \%$ of the total SOC (Tab. 1). The WSOC/SOC, HWSOC/SOC, and MBC/SOC ratios were higher in NPKS2 than in CK in the $0-10 \mathrm{~cm}$ soil layer $(P<0.05$, Tab. 1). The EOC/SOC ratios were higher in NPKS2 than in CK in the two soil layers $(P<0.05$, Tab. 1). The GMC values in the $0-10 \mathrm{~cm}$ and $10-20 \mathrm{~cm}$ soil layers were higher in NPKS2 than in the other treatments $(P<0.05$, Fig. 4).

\subsection{Soil CPMI}

In the $0-10 \mathrm{~cm}$ and $10-20 \mathrm{~cm}$ soil layers, the LI, CPI, and CPMI values were highest in the NPKS2 treatment, followed by NPKS1, NPK, and CK (Fig. 5). The LI, CPI, and CPMI values were higher in NPKS2 than in NPK and CK in the two soil layers $(P<0.05$, Fig. 5).

\subsection{Relationships among Different Organic C Fractions}

A correlation analysis indicated that the SOC concentrations were positively correlated with the WSOC, HWSOC, MBC, and EOC in the $0-10 \mathrm{~cm}$ and $10-20 \mathrm{~cm}$ soil layers $(P<0.05$, Tab. 2). Also, the soil labile organic $\mathrm{C}$ fractions were positively correlated with each other $(P<0.05$, Tab. 2).

\subsection{Soil C Turnover Related Enzyme Activities}

The soil cellulase activity was higher in NPKS2 than in CK in the $0-10 \mathrm{~cm}$ and $10-20 \mathrm{~cm}$ soil layers $(P<$ 0.05 , Fig. 6a), and the invertase activity was higher in NPKS2 than in CK in the $0-10 \mathrm{~cm}$ layer $(P<0.05$, Fig. 6b). However, no difference in $\beta$-glucosidase activities were found among the treatments in the two soil layers (Fig. 6c). The GMea values were higher in NPKS2 than in CK in both layers $(P<0.05$, Fig. 6d).

\subsection{Relationships between SOC Fractions and C Turnover Related Enzyme Activities}

In the Pearson's correlation analysis (Tab. 3), the cellulase activity in the $0-10 \mathrm{~cm}$ soil layer was positively correlated with WSOC, HWSOC, MBC, and EOC. In addition, there were positive relationships between the cellulase and both the HWSOC and EOC in the 10-20 cm soil layer $(P<0.05)$. The invertase activities in the two layers were positively correlated $(P<0.05)$ with most SOC fractions, except for the EOC in the $10-20 \mathrm{~cm}$ soil layer. The $\beta$-glucosidase activity was positively correlated with MBC and EOC in the $0-10 \mathrm{~cm}$ soil layer $(P<0.05)$. In the stepwise multiple regression analysis (Tab. 4), the models explained from $33.60 \%$ to $74.50 \%$ of the variation in total SOC and its fractions in the 0 $10 \mathrm{~cm}$ and $10-20 \mathrm{~cm}$ soil layers, and both the cellulase and invertase activities were the most significant variables in the models $(P<0.05)$. 

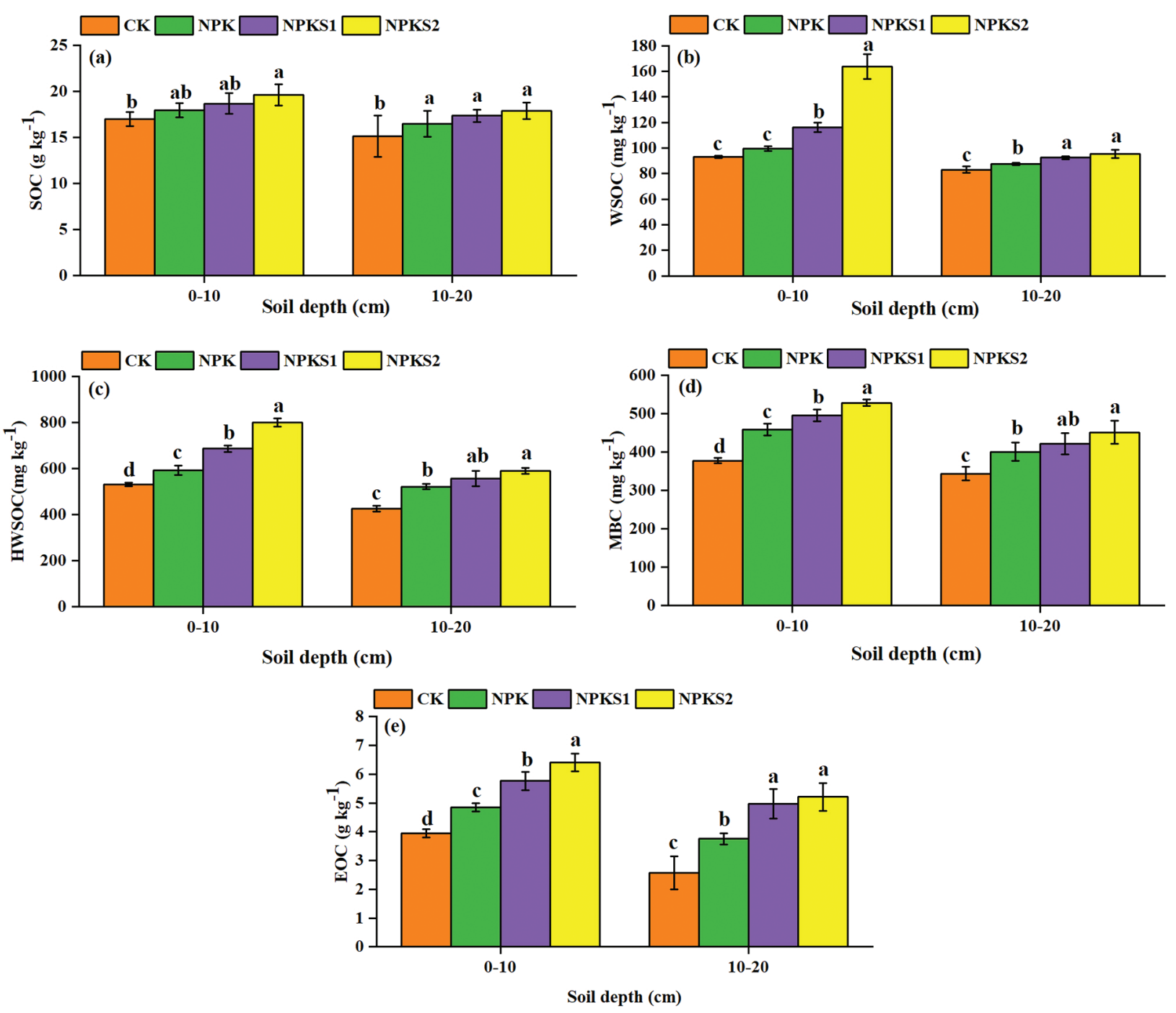

Figure 3: Changes in SOC fractions under different treatments. The values are means $\pm \operatorname{SD}(n=3)$. Different letters mean statistically significant differences at the 0.05 level. CK: no fertilizer and wheat straw; NPK: mineral nitrogen, phosphorus, and potassium fertilizers; NPKS1: moderate wheat straw $\left(3000 \mathrm{~kg} \mathrm{ha}^{-1}\right)$ combined with NPK; NPKS2: high wheat straw $\left(6000 \mathrm{~kg} \mathrm{ha}^{-1}\right)$ combined with NPK. SOC: soil organic C; WSOC: water soluble organic C; HWSOC: hot-water soluble organic C; MBC: microbial biomass C; EOC: easily oxidizable $\mathrm{C}$

\section{Discussion}

Similar to previous studies on crop straw management [14,36,37], our results indicated that a high straw incorporation rate led to higher SOC concentrations compared to not-fertilized treatment (CK). However, the straw incorporation at the moderate (NPKS1) and high (NPKS2) rates did not result in differences in SOC concentrations in comparison to the fertilized treatment (NPK). It is possible that the SOC concentration is generally insensitive to short-term management practices. This is because the changes in SOC content occur slowly and are comparatively small in comparison with the large background SOC content [6]. 
Table 1: The proportions of labile $\mathrm{C}$ fractions under different treatments

\begin{tabular}{llllll}
\hline Depth $(\mathrm{cm})$ & Treatment & WSOC/SOC $(\%)$ & HWSOC/SOC (\%) & MBC/SOC (\%) & EOC/SOC (\%) \\
\hline $0-10$ & CK & $0.55 \pm 0.03 \mathrm{~b}$ & $3.11 \pm 0.09 \mathrm{c}$ & $2.22 \pm 0.12 \mathrm{~b}$ & $23.11 \pm 1.31 \mathrm{~b}$ \\
& NPK & $0.55 \pm 0.03 \mathrm{~b}$ & $3.31 \pm 0.25 \mathrm{bc}$ & $2.56 \pm 0.19 \mathrm{a}$ & $26.95 \pm 1.83 \mathrm{~b}$ \\
& NPKS1 & $0.62 \pm 0.05 \mathrm{~b}$ & $3.69 \pm 0.27 \mathrm{ab}$ & $2.66 \pm 0.24 \mathrm{a}$ & $30.96 \pm 3.39 \mathrm{a}$ \\
& NPKS2 & $0.83 \pm 0.06 \mathrm{a}$ & $4.09 \pm 0.24 \mathrm{a}$ & $2.70 \pm 0.14 \mathrm{a}$ & $32.65 \pm 0.70 \mathrm{a}$ \\
$10-20$ & CK & $0.56 \pm 0.08 \mathrm{a}$ & $2.86 \pm 0.26 \mathrm{a}$ & $2.31 \pm 0.44 \mathrm{a}$ & $17.67 \pm 6.59 \mathrm{~b}$ \\
& NPK & $0.53 \pm 0.04 \mathrm{a}$ & $3.19 \pm 0.31 \mathrm{a}$ & $2.44 \pm 0.21 \mathrm{a}$ & $22.89 \pm 2.48 \mathrm{ab}$ \\
& NPKS1 & $0.53 \pm 0.03 \mathrm{a}$ & $3.21 \pm 0.25 \mathrm{a}$ & $2.43 \pm 0.21 \mathrm{a}$ & $28.68 \pm 3.68 \mathrm{a}$ \\
& NPKS2 & $0.53 \pm 0.04 \mathrm{a}$ & $3.14 \pm 0.16 \mathrm{a}$ & $2.52 \pm 0.06 \mathrm{a}$ & $29.20 \pm 3.94 \mathrm{a}$ \\
\hline
\end{tabular}

Note: The values are means $\pm \mathrm{SD}(n=3)$. Different letters in the same column mean significant differences at the 0.05 level in the Duncan's Multiple Range Test. CK: no fertilizer and wheat straw; NPK: mineral nitrogen, phosphorus, and potassium fertilizers; NPKS1: moderate wheat straw (3000 kg $\mathrm{ha}^{-1}$ ) combined with NPK; NPKS2: high wheat straw $\left(6000 \mathrm{~kg} \mathrm{ha}^{-1}\right)$ combined with NPK. SOC: soil organic C; WSOC: water soluble organic C; HWSOC: hot-water soluble organic C; MBC: microbial biomass C; EOC: easily oxidizable C.

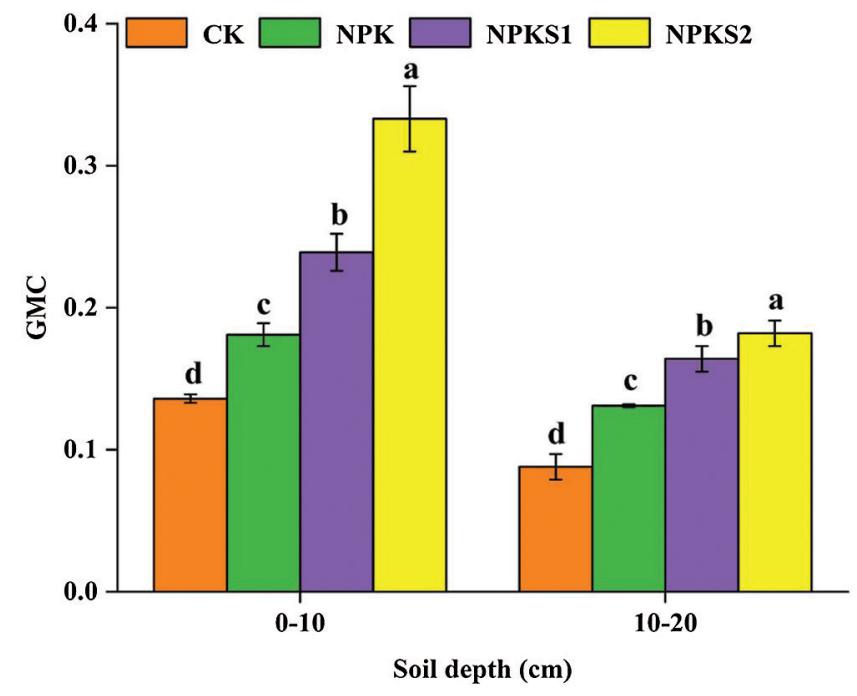

Figure 4: The GMC under different treatments. The values are means $\pm \mathrm{SD}(n=3)$. Different letters mean statistically significant differences at the 0.05 level. CK: no fertilizer and wheat straw; NPK: mineral nitrogen, phosphorus, and potassium fertilizers; NPKS1: moderate wheat straw $\left(3000 \mathrm{~kg} \mathrm{ha}^{-1}\right)$ combined with NPK; NPKS2: high wheat straw $\left(6000 \mathrm{~kg} \mathrm{ha}^{-1}\right)$ combined with NPK. GMC: the geometric means of labile $\mathrm{C}$ 

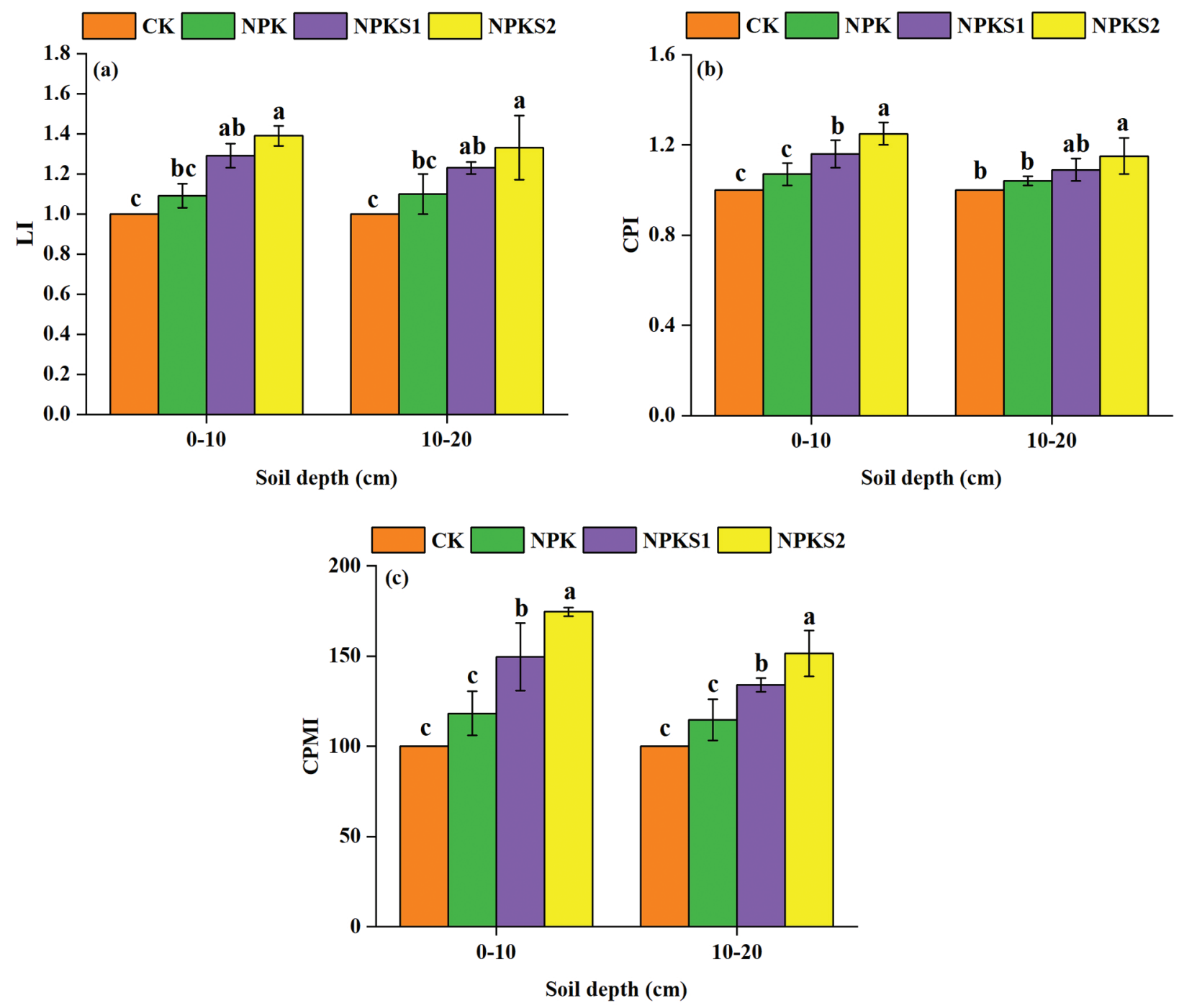

Figure 5: Changes in soil CPMI among different treatments. The values are means $\pm \operatorname{SD}(n=3)$. Different letters above the columns mean significant differences at the 0.05 level using the Duncan's Multiple Range Test. CK: no fertilizer and wheat straw; NPK: mineral nitrogen, phosphorus, and potassium fertilizers; NPKS1: moderate wheat straw $\left(3000 \mathrm{~kg} \mathrm{ha}^{-1}\right)$ combined with NPK; NPKS2: high wheat straw $\left(6000 \mathrm{~kg} \mathrm{ha}^{-1}\right.$ ) combined with NPK. LI: lability index; CPI: C pool index; CPMI: C pool management index 
Table 2: The correlation coefficients between SOC and the labile $\mathrm{C}$ fractions

\begin{tabular}{llllll}
\hline & SOC & WSOC & HWSOC & MBC & EOC \\
\hline $0-10 \mathrm{~cm}$ & & & & & \\
SOC & 1 & & & & \\
WSOC & $0.708^{* *}$ & 1 & & & \\
HWSOC & $0.741^{* *}$ & $0.951^{* *}$ & 1 & & \\
MBC & $0.696^{*}$ & $0.818^{* *}$ & $0.923^{* *}$ & 1 & \\
EOC & $0.750^{* *}$ & $0.880^{* *}$ & $0.959^{* *}$ & $0.975^{* *}$ & 1 \\
$10-20 \mathrm{~cm}$ & & & & & \\
SOC & 1 & & & & \\
WSOC & $0.628^{*}$ & 1 & & & \\
HWSOC & $0.621^{*}$ & $0.907^{* *}$ & 1 & & \\
MBC & $0.617^{*}$ & $0.789^{* *}$ & $0.912^{* *}$ & 1 & \\
EOC & $0.457^{*}$ & $0.890^{* *}$ & $0.852^{* *}$ & $0.724 * *$ & 1 \\
\hline $\begin{array}{l}\text { Note: } * *<<0.01 ; * P<0.05 . \text { SOC: soil organic C; WSOC: water soluble organic C; HWSOC: hot-water } \\
\text { soluble organic C; MBC: microbial biomass C; EOC: easily oxidizable C. }\end{array}$
\end{tabular}

The WSOC, HWSOC, MBC, and EOC concentrations respond to management practices more rapidly than the total SOC, making short-term changes easier to detect on them [38-39]. These fractions are considered as important indicators of changes in soil quality [2,39]. Generally, straw incorporation increased soil labile $\mathrm{C}$ fractions in the short time $[9,13,36,40]$. In this study, the concentrations of the labile C fractions (i.e., WSOC, HWSOC, MBC, and EOC concentrations) were higher in the NPKS2 treatment than in the NPK and CK treatments. This might be because crop straw contains large portions of labile $\mathrm{C}$ and is an important source of $\mathrm{C}$ and energy for microorganisms that convert crop straw $\mathrm{C}$ into labile organic $\mathrm{C}[10,41]$. The WSOC to SOC ratio was lower than the ratios of other C fractions to $\mathrm{SOC}$, but it played a key role in nutrient turnover and in the development of microbial populations. The ratios of HWSOC, MBC, and EOC to SOC were similar to those in previous studies [36,42-44]. In agreement with $\mathrm{Xu}$ et al. [9] and $\mathrm{Li}$ et al. [13], the straw incorporation increased the WSOC concentrations in the two soil layers. As with WSOC, we found that straw incorporation resulted in higher EOC concentrations in both layers, which is consistent with results reported in other studies [9,36]. For the HWSOC and MBC, the concentrations increased in the 10-20 cm soil layer only with the higher straw incorporation rate. Taken together, the response of WSOC and EOC was rapid and sensitive to soil management even in the short-term.

The geometric means of labile C (GMC) value integrates the responses of WSOC, HWSOC, MBC, and EOC into a single value that may be used as a sensitive indicator of the changes in SOC quantity or quality. Both the total SOC and the labile $\mathrm{C}$ fractions contribute to the $\mathrm{C}$ pool management index (CPMI) that is a sensitive indicator of the response of SOC to changes in soil management [5,9]. CPMI can detect small changes in the quantity and quality of SOC, and thereby it can be used to assess the efficacy of soil management practices $[4,9,39]$. In our study, the treatments were clearly different according to both the GMC and CPMI values, with highest values in the NPKS2 treatment. The results indicated that soil labile $\mathrm{C}$ was more sensitive to the NPKS2 than to the other treatments, and that the SOC was more stable in the NPKS2 treatment. The results suggested that the NPKS2 application had a positive influence on the accumulation of the soil $\mathrm{C}$ pool. 

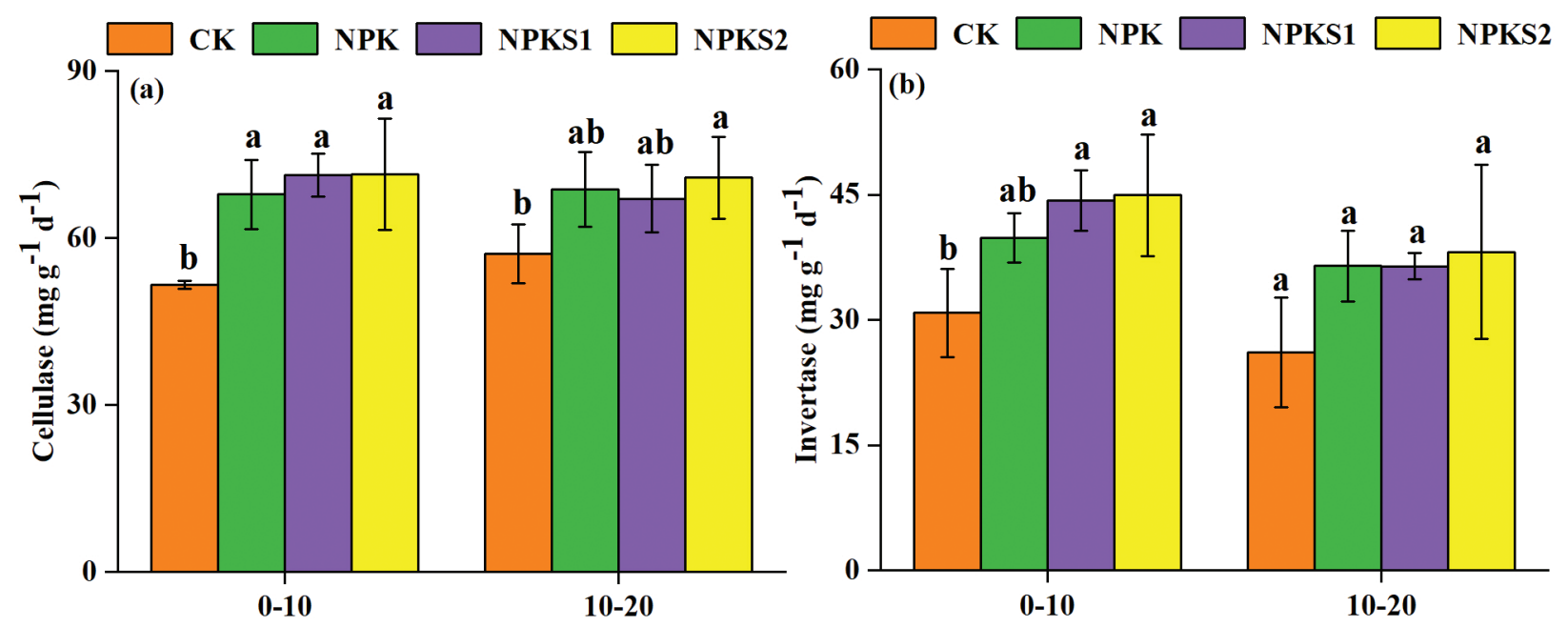

Soil depth (cm)
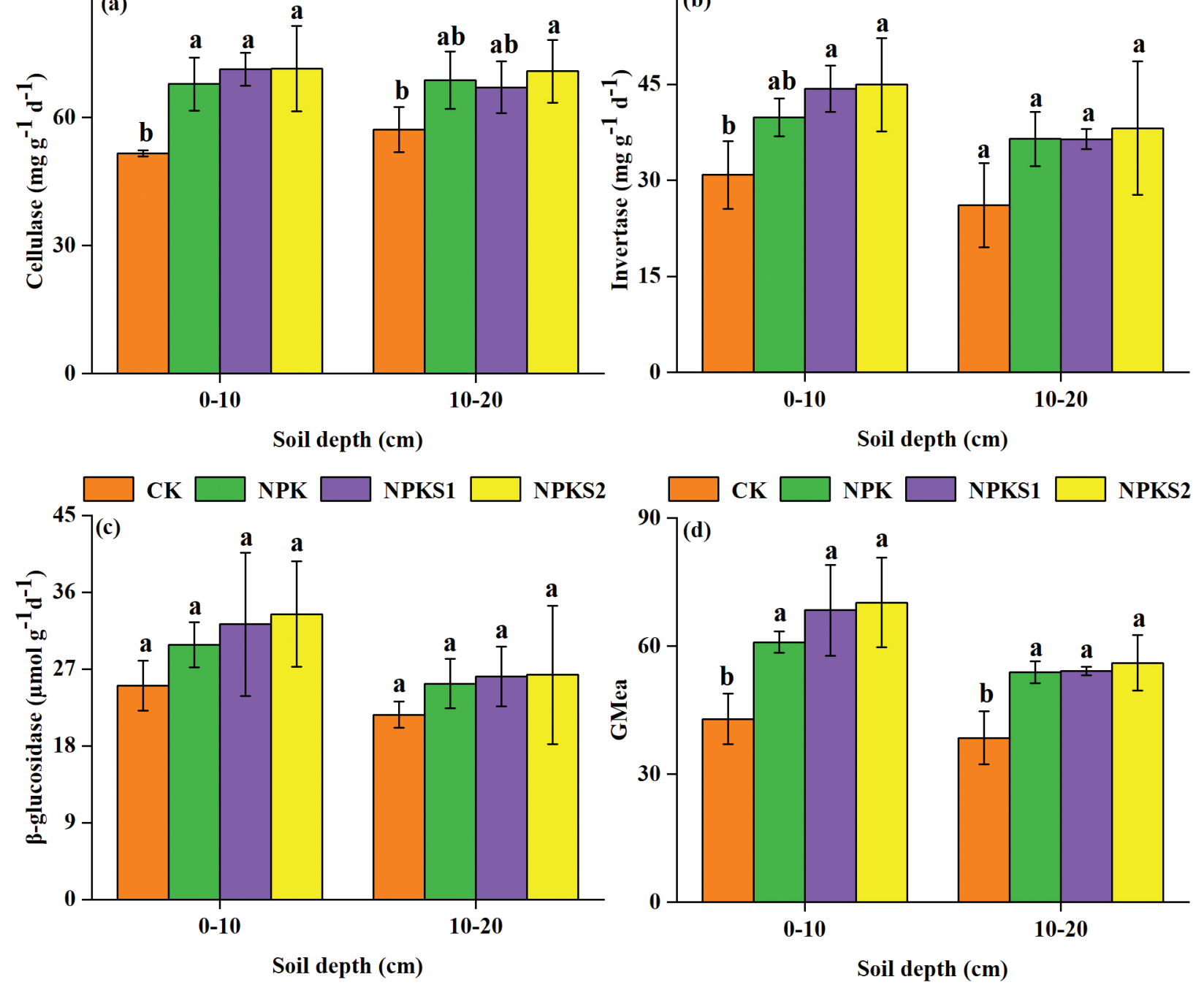

Figure 6: Soil $\mathrm{C}$ turnover related enzyme activities in response to different treatments. The values are means $\pm \mathrm{SD}(n=3)$. Different letters mean statistically significant differences at the 0.05 level. CK: no fertilizer and wheat straw; NPK: mineral nitrogen, phosphorus, and potassium fertilizers; NPKS1: moderate wheat straw $\left(3000 \mathrm{~kg} \mathrm{ha}^{-1}\right)$ combined with NPK; NPKS2: high wheat straw $\left(6000 \mathrm{~kg} \mathrm{ha}^{-1}\right)$ combined with NPK. GMea: the geometric mean of enzyme activities

Table 3: Pearson's correlation analysis between soil C turnover related enzyme activities and SOC fractions

\begin{tabular}{lllllll}
\hline Depth $(\mathrm{cm})$ & Index & SOC & WSOC & HWSOC & MBC & EOC \\
\hline $0-10$ & Cellulase & 0.575 & $0.577^{*}$ & $0.712^{* *}$ & $0.863^{* *}$ & $0.829^{* *}$ \\
& Invertase & $0.746^{* *}$ & $0.607^{*}$ & $0.706^{*}$ & $0.841^{* *}$ & $0.834^{* *}$ \\
& $\beta$-glucosidase & 0.250 & 0.411 & 0.483 & $0.605^{*}$ & $0.620^{*}$ \\
\multirow{2}{*}{$10-20$} & Cellulase & 0.339 & 0.412 & $0.607^{*}$ & 0.569 & $0.624^{*}$ \\
& Invertase & $0.580^{*}$ & $0.388^{*}$ & $0.591^{*}$ & $0.642^{*}$ & 0.412 \\
& $\beta$-glucosidase & 0.335 & 0.477 & 0.366 & 0.130 & 0.429 \\
\hline
\end{tabular}

Note: ${ }^{*} P<0.01 ; * P<0.05$. SOC: soil organic $\mathrm{C}$; WSOC: water soluble organic $\mathrm{C}$; HWSOC: hot-water soluble organic $\mathrm{C}$; MBC: microbial biomass $C$; EOC: easily oxidizable C. 
Table 4: Stepwise multiple regression analysis of the relationships between SOC fractions and soil C turnover related enzymes

\begin{tabular}{lllll}
\hline Depth $(\mathrm{cm})$ & SOC fractions & Regression equation & $R^{2}$ & $P$ \\
\hline $0-10$ & SOC & $Y=13.009+0.133 X_{2}$ & 0.557 & 0.005 \\
& WSOC & $Y=20.911+2.434 X_{2}$ & 0.369 & 0.036 \\
& HWSOC & $Y=156.400+7.578 X_{1}$ & 0.508 & 0.009 \\
& MBC & $Y=129.118+5.125 X_{1}$ & 0.745 & 0.000 \\
$10-20$ & EOC & $Y=0.673+0.114 X_{2}$ & 0.696 & 0.001 \\
& SOC & $Y=12.345+0.128 X_{2}$ & 0.336 & 0.048 \\
& WSOC & $Y=74.256+0.470 X_{2}$ & 0.345 & 0.045 \\
& HWSOC & $Y=179.101+5.227 X_{1}$ & 0.368 & 0.036 \\
& MBC & $Y=267.432+3.997 X_{2}$ & 0.412 & 0.024 \\
& EOC & $Y=-2.090+0.094 X_{1}$ & 0.390 & 0.030 \\
\hline
\end{tabular}

Note: SOC: soil organic C; WSOC: water soluble organic C; HWSOC: hot-water soluble organic C; EOC: easily oxidizable C; MBC: microbial biomass C. $Y$, SOC fractions. $X_{1}$ : cellulase; $X_{2}$ : invertase.

Consistent with previous studies $[2,45,46]$, the labile fractions correlated positively with the SOC concentration. This highlighted that SOC was a pivotal determinant of the labile $\mathrm{C}$ fractions. In addition, the labile fractions correlated positively with each other, showing that they were closely interrelated [45].

The activities of the soil enzymes are related to the soil nutrient cycling and serve as good indicators of soil quality [47]. Similar to earlier studies [48-50], the enzyme activities were higher in the NPKS2 treatment. Possibly crop straw addition led to higher amounts of endoenzymes in the viable microbial populations, and therefore more enzymes accumulated in the soils [50]. Consistent with Guo et al. [51], the soil cellulase activity was higher in NPKS2 than in CK, and the invertase activity was higher in NPKS2 than in CK in the top $10 \mathrm{~cm}$ soil. This may be attributable to higher SOC concentrations that enhanced the activity of soil microorganisms. The results indicated that the NPKS2 treatment improved soil quality by increasing the nutrient cycling and turnover in the soil. The geometric mean of enzyme activities (GMea) value can provide effective information on soil enzymes as indicators of soil quality [52]. In this study, the GMea values in the two soil layers were highest in NPKS2 and lowest in CK, suggesting that high amounts of straw residues could stimulate microbial growth.

Each $\mathrm{C}$ turnover related enzyme has its own substrate and ability to catalyze specific chemical and biological reactions [13,53]. Similar to $\mathrm{Li}$ et al. [13], the cellulase and invertase activities in the top $10 \mathrm{~cm}$ soil correlated positively with the labile fractions. These $\mathrm{C}$ turnover related enzymes degrade cellulose into labile organic $\mathrm{C}$ [54-55]. The correlations of cellulase and invertase were higher with MBC than with other fractions in the $0-10 \mathrm{~cm}$ soil layer, suggesting that these enzymes were mainly from soil microorganisms. Hence, high biomass turnover could increase microbial biomass and enzyme activities $[13,56]$. Assessing the roles of $\mathrm{C}$ turnover related enzymes in SOC turnover under straw incorporation using stepwise multiple linear regression demonstrated that the labile organic $\mathrm{C}$ formation was mostly enhanced by cellulase and invertase (Tab. 4), indicating that cellulase and invertase might increase the loss of SOC [13].

\section{Conclusion}

In this study, the total SOC concentrations were higher in the high rate of wheat straw incorporation treatment than in the not fertilized control, and the concentrations of labile $\mathrm{C}$ fractions were higher with 
wheat straw incorporation than without wheat straw. The treatments were clearly different according to both the GMC and CPMI values, with highest values in the high rate of wheat straw incorporation treatment. The concentrations of SOC and labile C fractions correlated positively. Soil cellulase activity and GMea were higher in the high rate of wheat straw incorporation treatment than in the not fertilized control. Soil cellulase and invertase activities enhanced the formation of SOC fractions. In conclusion, the high rate of wheat straw incorporation may be recommended to further increase SOC levels and soil fertility for sustainable agricultural development in the subtropical paddy fields.

Funding Statement: This work was funded by the Shanghai Agriculture Applied Technology Development Program, China (Grant No. G20190308) and the National Key Research and Development Program of China (2016YFD0801106).

Conflicts of Interest: The authors declare that they have no conflicts of interest to report regarding the present study.

\section{References}

1. Sarker, J. R., Singh, B. P., Dougherty, W. J., Fang, Y., Badgery, W. et al. (2018). Impact of agricultural management practices on the nutrient supply potential of soil organic matter under long-term farming systems. Soil \& Tillage Research, 175, 71-81. DOI 10.1016/j.still.2017.08.005.

2. Li, C. F., Yue, Z. K., Kou, Z. K., Zhang, Z. S., Wang, J. P. et al. (2012). Short-term effects of conservation management practices on soil labile organic carbon fractions under a rape-rice rotation in central China. Soil \& Tillage Research, 119, 31-37. DOI 10.1016/j.still.2011.12.005.

3. Guo, L. J., Zhang, Z. S., Wang, D. D., Li, C. F., Cao, C. G. (2015). Effects of short-term conservation management practices on soil organic carbon fractions and microbial community composition under a rice-wheat rotation system. Biology and Fertility of Soils, 51, 65-75. DOI 10.1007/s00374-014-0951-6.

4. Li, J., Wen, Y. C., Li, X. H., Li, Y. T., Yang, X. D. et al. (2018). Soil labile organic carbon fractions and soil organic carbon stocks as affected by long-term organic and mineral fertilization regimes in the North China Plain. Soil \& Tillage Research, 175, 281-290. DOI 10.1016/j.still.2017.08.008.

5. Blair, G. J., Lefroy, R. D. B., Lisle, L. (1995). Soil carbon fractions, based on their degree of oxidation and the development of a carbon management index for agricultural systems. Australian Journal Agricultural Research, 46, 1459-1466. DOI 10.1071/AR9951459.

6. Gong, W., Yan, X., Wang, J., Hu, T., Gong, Y. (2009a). Long-term manure and fertilizer effects on soil organic matter fractions and microbes under a wheat-maize cropping system in northern China. Geoderma, 149, 318324. DOI 10.1016/j.geoderma.2008.12.010.

7. Dai, W., Zhao, K. L., Fu, W. J., Jiang, P. K., Li, Y. F. et al. (2018). Spatial variation of organic carbon density in topsoils of a typical subtropical forest, southeastern China. Catena, 167, 181-189. DOI 10.1016/j. catena.2018.04.040.

8. Sparling, G., Vojvodic-Vukovic, M., Schipper, L. A. (1998). Hot-water-soluble C as a simple measure of labile soil organic matter: The relationship with microbial biomass C. Soil Biology and Biochemistry, 30, 1469-1472. DOI 10.1016/S0038-0717(98)00040-6.

9. Xu, M., Lou, Y., Sun, X., Wang, W., Baniyamuddin, M. et al. (2011). Soil organic carbon active fractions as early indicators for total carbon change under straw incorporation. Biology and Fertility of Soils, 47, 745-752. DOI 10.1007/s00374-011-0579-8.

10. Liu, C., Lu, M., Cui, J., Li, B., Fang, C. M. (2014). Effects of straw carbon input on carbon dynamics in agricultural soils: A meta-analysis. Global Change Biology, 20, 1366-1381. DOI 10.1111/gcb.12517.

11. Chen, Z. M., Wang, H. Y., Liu, X. W., Zhao, X. L., Lu, D. J. et al. (2017). Changes in soil microbial community and organic carbon fractions under short-term straw return in a rice-wheat cropping system. Soil \& Tillage Research, 165, 121-127. DOI 10.1016/j.still.2016.07.018. 
12. Tian, K., Zhao, Y., Xu, X., Hai, N., Huang, B. et al. (2015). Effects of long-term fertilization and residue management on soil organic carbon changes in paddy soils of China: A meta-analysis. Agriculture, Ecosystems and Environment, 204, 40-50. DOI 10.1016/j.agee.2015.02.008.

13. Li, S., Zhang, S. R., Pu, Y. L., Li, T., Xu, X. X. et al. (2016). Dynamics of soil labile organic carbon fractions and C-cycle enzyme activities under straw mulch in Chengdu Plain. Soil \& Tillage Research, 155, 289-297. DOI 10.1016/j.still.2015.07.019.

14. Wang, X. J., Jia, Z. K., Liang, L. Y., Zhao, Y. F., Yang, B. P. et al. (2018). Changes in soil characteristics and maize yield under straw returning system in dryland farming. Field Crops Research, 218, 11-17. DOI 10.1016/j. fcr.2017.12.003.

15. Wang, Q. K., Xiao, F. M., He, T. X., Wang, S. L. (2013). Responses of labile soil organic carbon and enzyme activity in mineral soils to forest conversion in the subtropics. Annals Forest Science, 70, 579-587. DOI 10.1007/s13595-013-0294-8.

16. Lin, Z. W., Li, Y. F., Tang, C. X., Luo, Y., Fu, W. J. et al. (2018). Converting natural evergreen broadleaf forests to intensively managed moso bamboo plantations affects the pool size and stability of soil organic carbon and enzyme activities. Biology and Fertility of Soils, 54, 467-480. DOI 10.1007/s00374-018-1275-8.

17. Bowles, T. M., Acosta-Martínez, V., Calderón, F., Jackson, L. E. (2014). Soil enzyme activities, microbial communities, and carbon and nitrogen availability in organic agroecosystems across an intensively-managed agricultural landscape. Soil Biology and Biochemistry, 68, 252-262. DOI 10.1016/j.soilbio.2013.10.004.

18. Kotroczó, Z., Veres, Z., Fekete, I., Krakomperger, Z., Tóth, J. A. et al. (2014). Soil enzyme activity in response to long-term organic matter manipulation. Soil Biology and Biochemistry, 70, 237-243. DOI 10.1016/j. soilbio.2013.12.028.

19. Ameloot, N., Sleutel, S., Das, K. C., Kanagaratnam, J., Neve, S. (2015). Biochar amendment to soils with contrasting organic matter level: Effects on $\mathrm{N}$ mineralization and biological soil properties. Global Change Biology, 7, 135-144. DOI 10.1111/gcbb.12119.

20. Keeler, B. L., Hobbie, S. E., Kellogg, L. E. (2009). Effects of long-term N addition on microbial enzyme activity in eight forested and grassland sites: Implications for litter and soil organic matter decomposition. Ecosystems, 12, 115. DOI 10.1007/s10021-008-9199-z.

21. Ananbeh, H., Stojanović, M., Pompeiano, A., Voběrková, S., Trasar-Cepeda, C. (2019). Use of soil enzyme activities to assess the recovery of soil functions in abandoned coppice forest systems. Science of the Total Environment, 694, 133692. DOI 10.1016/j.scitotenv.2019.133692.

22. Wu, J. (2011). Carbon sequestration in paddy ecosystems in subtropical China: Evidence from landscape studies. European Journal of Soil Science, 62, 29-34. DOI 10.1111/j.1365-2389.2010.01325.x.

23. Liu, Y. L., Ge, T. D., Zhu, Z. K., Liu, S. L., Luo, Y. et al. (2019). Carbon input and allocation by rice into paddy soils: A review. Soil Biology and Biochemistry, 133, 97-107. DOI 10.1016/j.soilbio.2019.02.019.

24. Tang, H. Y., Liu, Y., Li, X. M., Muhammad, A., Huang, G. Q. (2019). Carbon sequestration of cropland and paddy soils in China: Potential, driving factors, and mechanisms. Greenhouse Gases: Science and Technology, 9, 872885. DOI 10.1002/ghg.1901.

25. Morrissey, E. M., Berrier, D. J., Neubauer, S. C., Franklin, R. B. (2014). Using microbial communities and extracellular enzymes to link soil organic matter characteristics to greenhouse gas production in a tidal freshwater wetland. Biogeochemistry, 117, 473-490. DOI 10.1007/s10533-013-9894-5.

26. Fang, Y., Nazaries, L., Singh, B. K., Singh, B. P. (2018). Microbial mechanisms of carbon priming effects revealed during the interaction of crop residue and nutrient inputs in contrasting soils. Global Change Biology, 24, 27752790. DOI $10.1111 / \mathrm{gcb} .14154$.

27. Xia, L. L., Wang, S. W., Yan, X. Y. (2014). Effects of long-term straw incorporation on the net global warming potential and the net economic benefit in a rice-wheat cropping system in China. Agriculture, Ecosystems and Environment, 197, 118-127. DOI 10.1016/j.agee.2014.08.001.

28. Wang, S. X., Zhang, C. Y. (2008). Spatial and temporal distribution of air pollutant emissions from open burning of crop residues in China. Science Paper Online, 3, 329-333 (in Chinese). 
29. Xiao, Y. (2012). The analysis of straw burning and use. Journal of Green Science Tecnology, 11, 72-74 (in Chinese).

30. Wu, J. S., Jiang, P. K., Chang, S. X., Xu, Q. F., Yang, L. (2010). Dissolved soil organic carbon and nitrogen were affected by conversion of native forests to plantations in subtropical China. Canadian Journal of Soil Science, 90, 27-36. DOI 10.4141/CJSS09030.

31. Vance, E. D., Brookes, P. C., Jenkinson, D. C. (1987). An extraction method for measuring soil microbial biomass C. Soil Biology and Biochemistry, 19, 703-707. DOI 10.1016/0038-0717(87)90052-6.

32. Yu, P. J., Liu, S. W., Han, K. X., Guan, S. C., Zhou, D. W. (2017). Conversion of cropland to forage land and grassland increases soil labile carbon and enzyme activities in northeastern China. Agriculture, Ecosystems and Environment, 245, 83-91. DOI 10.1016/j.agee.2017.05.013.

33. Guan, S. Y. (1986). Soil enzymes and its methodology. Beijing: Agricultural Press (in Chinese).

34. Geng, Y., Dighton, J., Gray, D. (2012). The effects of thinning and soil disturbance on enzyme activities under pitch pine soil in New Jersey pinelands. Applied Soil Ecology, 62, 1-7. DOI 10.1016/j.apsoil.2012.07.001.

35. Roberto, G. A. R., Ochoa, V., ViñEgla, B., Hinojosa, M. B., PeñA-Santiago, R. et al. (2009). Soil enzymes, nematode community and selected physico-chemical properties as soil quality indicators in organic and conventional olive oil farming: Influence of seasonality and site features. Applied Soil Ecology, 41, 305-314. DOI 10.1016/j.apsoil.2008.12.004.

36. Zhu, L. Q., Hu, N. J., Zhang, Z. W., Xu, J. L., Tao, B. R. et al. (2015). Short-term responses of soil organic carbon and carbon pool management index to different annual straw return rates in a rice-wheat cropping system. Catena, 135, 283-289. DOI 10.1016/j.catena.2015.08.008.

37. Huang, W., Wu, J. F., Pan, X. H., Tan, X. M., Zeng, Y. J., Shi, Q. H., Liu, T. J., Zeng, Y. H. (2021). Effects of longterm straw return on soil organic carbon fractions and enzyme activities in a double-cropped rice paddy in south China. Journal of Integrative Agriculture, 20, 236-247. DOI 10.1016/S2095-3119(20)63347-0.

38. Janzen, H. H., Campbell, C. A., Brandt, S. A., Lafond, G. P., Townley-Smith, L. (1992). Light fraction organic matter in soils from long-term crop rotations. Soil Science Society of America Journal, 56, 1799-1806. DOI 10.2136/sssaj1992.03615995005600060025x.

39. Haynes, R. J., (2005). Labile organic matter fractions as central components of the quality of agricultural soils: An overview. Advances in Agronomy, 85, 221-268. DOI 10.1016/S0065-2113(04)85005-3.

40. Roper, M. M., Gupta, V. V. S. R., Murphy, D. V. (2010). Tillage practices altered labile soil organic carbon and microbial function without affecting crop yields. Australian Journal Agricultural Research, 48, 274-285. DOI 10.1071/SR09143.

41. Wu, L., Zhang, W. J., Wei, W. J., He, Z. L., Kuzyakov, Y. et al. (2019). Soil organic matter priming and carbon balance after straw addition is regulated by long-term fertilization. Soil Biology and Biochemistry, 135, 383391. DOI 10.1016/j.soilbio.2019.06.003.

42. Ghani, A., Dexter, M., Perrot, K. W. (2003). Hot-water extractable carbon in soils, a sensitive measurement for determining impacts of fertilization, grazing and cultivation. Soil Biology and Biochemistry, 35, 1231-1243. DOI 10.1016/S0038-0717(03)00186-X.

43. Gong, W., Yan, X., Wang, J., Hu, T., Gong, Y. (2009b). Long-term manuring and fertilization effects on soil organic carbon pools under a wheat-maize cropping system in North China Plain. Plant and Soil, 149, 318 324. DOI 10.1007/s11104-008-9705-2.

44. Wang, W., Lai, D. Y. F., Wang, C., Pan, T., Zeng, C. (2015). Effects of rice straw incorporation on active soil organic carbon pools in a subtropical paddy field. Soil \& Tillage Research, 152, 8-16. DOI 10.1016/j. still.2015.03.011.

45. Chen, H. Q., Hou, R. X., Gong, Y. S., Li, H. W., Fan, M. S. et al. (2009). Effects of 11 years of conservation tillage on soil organic matter fractions in wheat monoculture in loess plateau of China. Soil \& Tillage Research, 106, 85-94. DOI 10.1016/j.still.2009.09.009.

46. Duval, M. E., Galantini, J. A., Martínez, J. M., Limbozzi, F. (2018). Labile soil organic carbon for assessing soil quality: Influence of management practices and edaphic conditions. Catena, 171, 316-326. DOI 10.1016/j. catena.2018.07.023. 
47. Sinsabaugh, R. L., Lauber, C. L., Weintraub, M. N., Ahmed, B., Allison, S. D. et al. (2008). Stoichiometry of soil enzyme activity at global scale. Ecology Letters, 11, 1252-1264. DOI 10.1111/j.1461-0248.2008.01245.x.

48. Gianfreda, L., Rao, M. A., Piotrowska, A., Palumbo, G., Colombo, C. (2005). Soil enzyme activities as affected by anthropogenic alterations: Intensive agricultural practices and organic pollution. Science of the Total Environment, 341, 265-279. DOI 10.1016/j.scitotenv.2004.10.005.

49. Wei, T., Zhang, P., Wang, K., Ding, R., Yang, B. et al. (2015). Effects of wheat straw incorporation on the availability of soil nutrients and enzyme activities in semiarid areas. PLoS One, 10, e0120994. DOI 10.1371/ journal.pone.0120994.

50. Zhang, P., Chen, X. L., Wei, T., Yang, Z., Jia, Z. K. et al. (2016). Effects of straw incorporation on the soil nutrient contents, enzyme activities, and crop yield in a semiarid region of China. Soil \& Tillage Research, 160, 65-72. DOI 10.1016/j.still.2016.02.006.

51. Guo, T., Zhang, Q., Ai, C., Liang, G., He, P. et al. (2018). Nitrogen enrichment regulates straw decomposition and its associated microbial community in a double-rice cropping system. Scientific Reports, 8(1), 1847. DOI 10.1038/ s41598-018-20293-5.

52. Li, T., Gao, J. S., Bai, L. Y., Wang, Y. N., Huang, J. et al. (2019). Influence of green manure and rice straw management on soil organic carbon, enzyme activities, and rice yield in red paddy soil. Soil \& Tillage Research, 195, 104428. DOI 10.1016/j.still.2019.104428.

53. Salazar, S., Sánchez, L. E., Alvarez, J., Valverde, A., Galindo, P. et al. (2011). Correlation among soil enzyme activities under different forest system management practices. Ecological Engineering, 37, 1123-1131. DOI 10.1016/j.ecoleng.2011.02.007.

54. Wickings, K., Grandy, A. S., Reed, S. C., Cleveland, C. C. (2012). The origin of litter chemical complexity during decomposition. Ecology Letters, 15, 1180-1188. DOI 10.1111/j.1461-0248.2012.01837.x.

55. Tan, X. P., Xie, B. N., Wang, J. X., He, W. X., Wang, X. D. et al. (2014). County-scale spatial distribution of soil enzyme activities and enzyme activity indices in agricultural land: Implications for soil quality assessment. Scientific World Journal, 11, 535768. DOI 10.1155/2014/535768.

56. He, Z. L., Yang, X. E., Baligar, V. C., Calvert, D. V. (2003). Microbiological and biochemical indexing systems for assessing acid soil quality. Advances in Agronomy, 78, 89-138. DOI 10.1016/S0065-2113(02)78003-6. 